\title{
Defining the Differences in Corporate Culture in Wood- processing and Forest Enterprises
}

\begin{abstract}
Silvia Lorincová, ${ }^{\mathrm{a}}$ Katarína Stachová, ${ }^{\mathrm{b}}$ Zdenko Stacho, ${ }^{\mathrm{b}}$ Zuzana Joniaková, ${ }^{\mathrm{c}}$ Jana Blštáková, ${ }^{\mathrm{c}}$ Martina Lipoldová, ${ }^{\mathrm{a}}$ and Miloš Hitka ${ }^{\mathrm{a}, *}$

Corporate culture represents a personality of a company. Suitable corporate culture should be a summary of behavior and action of the company as a whole and its individual employees on their way to achieving the strategic goals of the company. Using the Organizational Culture Assessment Instrument methodology, the corporate culture on a sample of 1,114 respondents in wood-processing and forest enterprises in Slovakia is defined and compared. The hypothesis that there were statistically significant differences between wood-processing and forest enterprises in individual components of corporate culture is confirmed in the paper. The differences in the perception of corporate culture in the area of organizational leadership and criteria of success can be considered the research output. In the area of organizational leadership, there are significant differences in the respondents' opinions. In the area of criteria of success, employees of the wood-processing enterprises preferred the success of these companies based on the development of human resources and teamwork. There were no significant differences in the area of overall corporate culture. Both groups of employees preferred clan corporate culture.
\end{abstract}

Keywords: Corporate culture; Wood processing enterprises; Forest enterprises; OCAI; t-test

Contact information: a: Technical University in Zvolen, T. G. Masaryka 24, 96053 Zvolen, Slovakia; b: Institute of Civil Society, University of St. Cyril and Methodius, Trnava 917 01, Slovakia; c: Department of Management, Faculty of Business Management, University of Economics in Bratislava, Dolnozemská cesta 1, 85235 Bratislava, Slovakia; *Corresponding author: hitka@tuzvo.sk

\section{INTRODUCTION}

The continuing economic intensification of globalization motivates enterprises to create strategies that can help them to succeed in a hyper-competitive environment (Lizbetinova 2014; Kucharciková et al. 2015; Musová 2015; Nedeliakova and Panak 2015; Poliačiková 2015; Bartuška et al. 2016a, b; Ližbetin et al. 2016; Nedeliakova et al. 2016; Potkany et al. 2016; Lizbetinova 2017; Nemec et al. 2017; Oblak et al. 2017; Zaborova et al. 2017; Jenco et al. 2018; Loucanova et al. 2018; Nyvlt 2018; Anyakoha 2019; Horváth and Hollósy 2019; Kohnová et al. 2019; Nyuur et al. 2020). Therefore, focusing on performance is crucial in an effort to survive. In this context, the corporate culture represents a major element of business management, which is supported by existing studies (Ogbonna and Harris 2000; Škerlavaj et al. 2011; Rezaei et al. 2016; Mullakhmetov et al. 2019; Vlaicu et al. 2019) and has a significant impact on their performance. An overview of actual literature associated with the corporate culture is given in this paper.

Corporate culture represents a personality of a company; suitable corporate culture should be a summary of behavior and action of both the company as a whole and its 
individual employees on their way to achieve strategic goals of the company (Jahanian and Amini 2015), as well as employees' personal objectives (Muhtadi et al. 2013). On a general level, climate perceptions are viewed as a way to provide a mediating link between organizational characteristics and employee attitudes, motivation, and performance (Parker et al. 2003). Organizational culture, teamwork, and organizational development have a direct and significant effect on organizational commitment (Ghorbanhosseini 2013). For this reason, good examples of leader behaviors are desirable, which may in turn effectively motivate employees to follow them (Huang et al. 2008). This indicated that if the employees were internally in agreement with the set corporate culture, they also had internal motivation to act and behave in accordance with the corporate culture, because this behavior was natural for them and the work environment was satisfactory.

The existing culture of the organization is externally manifested by the external elements of culture. Like the symbolic artifacts of material nature (badges, logos, pictures, style, correspondence format, building architecture, etc.), the verbal symbols (jargon, jokes, metaphors, proverbs, slogans, stories, legends, myths, sagas, etc.), the symbolic behavior and acting (traditions, behavioral norms, codes, rituals, ceremonials, etc.), the status symbols (traditional designations of job functions like president, inspector, etc.), various titles awarded in recognition of employee's work (e.g., the best employee in the organization), or the tangible assets pertaining to the individual, in particular to the higher functions (size, location, and equipment in the office with furniture, art, plants, secretary, company car, cellphone, membership of clubs, business cards, etc.) (Stacho and Stachova 2015) all exhibit corporate culture.

The corporate culture can be affected in a relatively easy way, primarily using direct measures because they can be clearly named and easy to understand and grasped by the employees. However, it is considerably more difficult to affect the internal elements of culture, such as values, opinions, and convictions. It is not sufficient only to adopt direct measures for the employees to internalize them; it is necessary to affect the employees through indirect tools. A major factor is employee motivation, both internal (agreement between the values of the employee and the values of the organization) and external in the form of stimuli characterizing the reward system as a method of clear expression of the values of the organization. This is a key factor for the employees to understand corporate culture (Brown 1995; Da Silva et al. 2010; Kropivšek et al. 2011; Kmecová 2018; Kucharčíková and Mičiak 2018; Sánchez-Sellero et al. 2018). An important role of this activity is played by the employee's supervisor, who should be in the position of instructor. A system of individual functions for managing human resources plays an important role as well, through which the suitable culture can be spread and promote (Bajzikova et al. 2013; Joniakova and Blstakova 2015; Urbancova et al. 2016; Kucharčíková and Mičiak 2017; Cagáňová et al. 2019; Remisova et al. 2019).

Unfortunately, in terms of management, corporate culture is one of the so-called soft areas, which are inherently difficult to measure, and therefore the leader of the organization considers it as an additional activity during crisis or troublesome periods of the organization. Although the suitable corporate culture is pushed to the background, it has direct effect on the performance and resulting financial success of the organization (Ogbonna and Harris 2000; Škerlavaj et al. 2011; Rezaei, et al. 2016). Based on this present research, suitable corporate culture contributes to the long-term sustainability of business performance and it is a source of competitive advantage (Scott 1997; Colyer 2000; McShane and Von Glinow 2000; Yong and Pheng 2008; Cheung et al. 2011; Vallejo-Martos 
2011; Cui and Hu 2012; Vetraková et al. 2015; Nukic and Huemann 2016; Vetraková and Smerek 2016; Papula et al. 2018). It is clear that corporate culture reduces conflicts, ensures continuity, facilitates and simplifies coordination and control, reduces employee insecurity and affects their work satisfaction and emotional wellbeing. Moreover, it can be a major source of motivation and a competitive advantage (Lukášová 2010). The justification of corporate culture and its effects on performance, profitability, and business sustainability have been constantly confirmed by authors like Deal and Kennedy (1982), Denison and Spreitzer (1991), Kotter and Heskett (1992), Kreitner and Kinicki (2001), Lencioni (2002), Cameron and Quinn (2006), Ravasi and Schultz (2006), Hofstede et al. (2007), RadovicMarkovic (2008), Cheung et al. (2011), Vallejo-Martos (2011), Belias et al. (2015), Schein and Schein (2016), Coyle (2018), and many others since the 1980s. The survey conducted by Armstrong Competence Consulting Company (2009) showed that up to one fifth of employee performance could be explained by the differences in corporate culture. Given this, there can be no doubt about the importance and effect of corporate culture on employee performance.

Clear corporate culture is becoming an important added value of products and services offered by an organization in the market, a determinant of relationships between business and other partners, but mostly a differentiating aspect of the organization in terms of present and potential employees as well as a tool to manage and motivate people in the organization (Uriga and Obdržálek 2009). However, in terms of the practical implementation, it is important for the top managers to realize the corporate culture as an actual tool affecting staff intentionally and systematically (perfect, motivate, cultivate, and manage) and ensuring the long-term achievement from the desired performance level of a given organization (Kachaňáková and Stachová 2014).

Corporate culture strength and content depend on the specific organization and its conditions. The content of corporate culture consists of basic assumptions, values, behavioral standards, attitudes, and artefacts (Jančíková 2005). The strength of corporate culture is defined by the coherence, homogeneity, stability, and intensity of values or the measure of their infiltration (Lukášová and Nový 2004). The content of the culture is embodied through the behavior and artefacts. Some researchers (Saffold 1988; Gordon and Ditomaso 1992) attempted to define specific values of the enterprises in relation to performance and business success. Many studies (Kotter and Heskett 1992; Pfeifer and Umlaufová 1993; Lukášová and Nový 2004; Hofstede et al. 2007; Armstrong Competence Consulting Company 2009; Kachaňáková 2010) agreed that for high business performance it is necessary the content of corporate culture agrees with external environment, conditions of the sector, and business strategy to match the context. The greater the agreement between the corporate culture and the context of the business, the better results the enterprise will be able to achieve.

One of the tools allowing managers to divide, classify, clarify, and analyze the complicated content of social reality is the construction of typologies. Types or typologies as sets of types are a learning tool that makes it possible to simplify and, to a certain extent, to organize otherwise intricate and complicated content of reality. They are developed in two ways: theoretically and empirically. Theoretically, the constructed types are planned, created systems of selected characteristics of given phenomenon. The selection of the characteristics is governed primarily by the effort devoted to simplify the complexities of classes of phenomena and to capture the most essential characteristics, which can create differences between individual groups of phenomena. They are created to describe, 
compare, and predict actual events. The purpose of the empirical typologies is similar, but they are created using an analysis of empirical data and subsequently they are theoretically conceptualized.

In the area of corporate culture, the development of typologies is a relatively popular subject. The existing typologies identify the typical content of corporate culture from different perspectives, in relation to the different purpose, such as the analytical approach (Harrison 1972; Handy 1985), the levels of business risk and market feedback (Deal and Kennedy 1982; Steinmann and Schreyögg 1993), the flexibility level vs. control and rate of internal vs. external focus (OCAI) (Quinn and Rohrbaugh 1983), dominant orientation during change, business lifecycle (Kachaňáková et al. 1997), types of employees (McNamara 2006), mental state of the employees (Kets de Vries and Miller 1984), possibility of change (Bowett 2006), or the method of business' adaptation to internal environment (Miles and Snow 1978). Despite the fact that the typologies of corporate cultures represent a great simplification and do not capture all aspects of life of the organization, they represent certain basic types, and some can be found with certain modifications in many organizations. Parallel coexistence of two or several types of these cultures can be encountered. The typologies have a theoretical meaning that they deepen scientific understanding in a given field (Deal and Kennedy 1982; Denison and Spreitzer 1991; Kotter and Heskett 1992; Cameron and Quinn 2006; Belias et al. 2015; Schein and Schein 2016; Coyle 2018), and a practical meaning that they allow managers to compare the content of their corporate culture with typical, real-life cases (Yeung et al. 1991; Zammuto and Krakower 1991; Wilderom et al. 2000; Parthasarathy and Ramalingam 2015; Willar et al. 2016; Bergman et al. 2017). Typical situations when organization management needs to know and understand the content of corporate culture are for example the development of business strategy, solving the issue of difficult implementation of the selected strategy, searching for reasons for low business performance, or planning the business mergers, acquisitions, etc.

Comparing the corporate culture in wood-processing and forest enterprises, and subsequently, defining the preferred corporate culture in the analyzed organizations and their differences is the goal of this paper.

\section{EXPERIMENTAL}

The research into corporate culture was conducted throughout the years 2016 and 2019. Employees of wood-processing enterprises (WPE) and forest enterprises (FE) in Slovakia were addressed using the random selection method. In the case of woodprocessing enterprises, employees working in wood, furniture, and cellulose-paper enterprises were addressed. The wood-processing industry is an important part of the industry in the Slovak Republic. It is relatively independent on the import of natural resources and it also allows the development of small and medium-sized enterprises (Suchomel and Gejdos 2007; Hajdúchová et al. 2016; Mala et al. 2019; Palus et al. 2019). Employees of forest enterprises participated in the research as well. In terms of fulfilling nationwide functions, they play the most important role in the Slovak economy (Forest Europe 2015; Balážová and Luptáková 2016; Ministerstvo Pôdohospodárstva a Rozvoja Vidieka Slovenskej Republiky 2017; Koval'ová et al. 2018; Parobek et al. 2019). The forest sector represents $0.33 \%$ of the gross domestic product (GDP) in the Slovak Republic. There 
are between 1,200 and 1,300 enterprises in this sector. The profits range between 220 and 240 million Euros. Due to the historical development, this specific sector is dominated by men (3:1 ratio) with a secondary education completed (Suchomel and Gejdos 2010; Paluš et al. 2011; Sujová and Kovalčík 2017; Halaj et al. 2018).

\section{Data Collection and Sample Size}

The research employed the social survey methodology via anonymous questionnaires. The questionnaire consisted of two parts. The first part of the questionnaire examined the basic socio-demographic characteristics (gender, age, completed education, number of years worked in the business, and job category). The composition of the research sample is presented in Table 1.

Table 1. Composition of the Research Sample

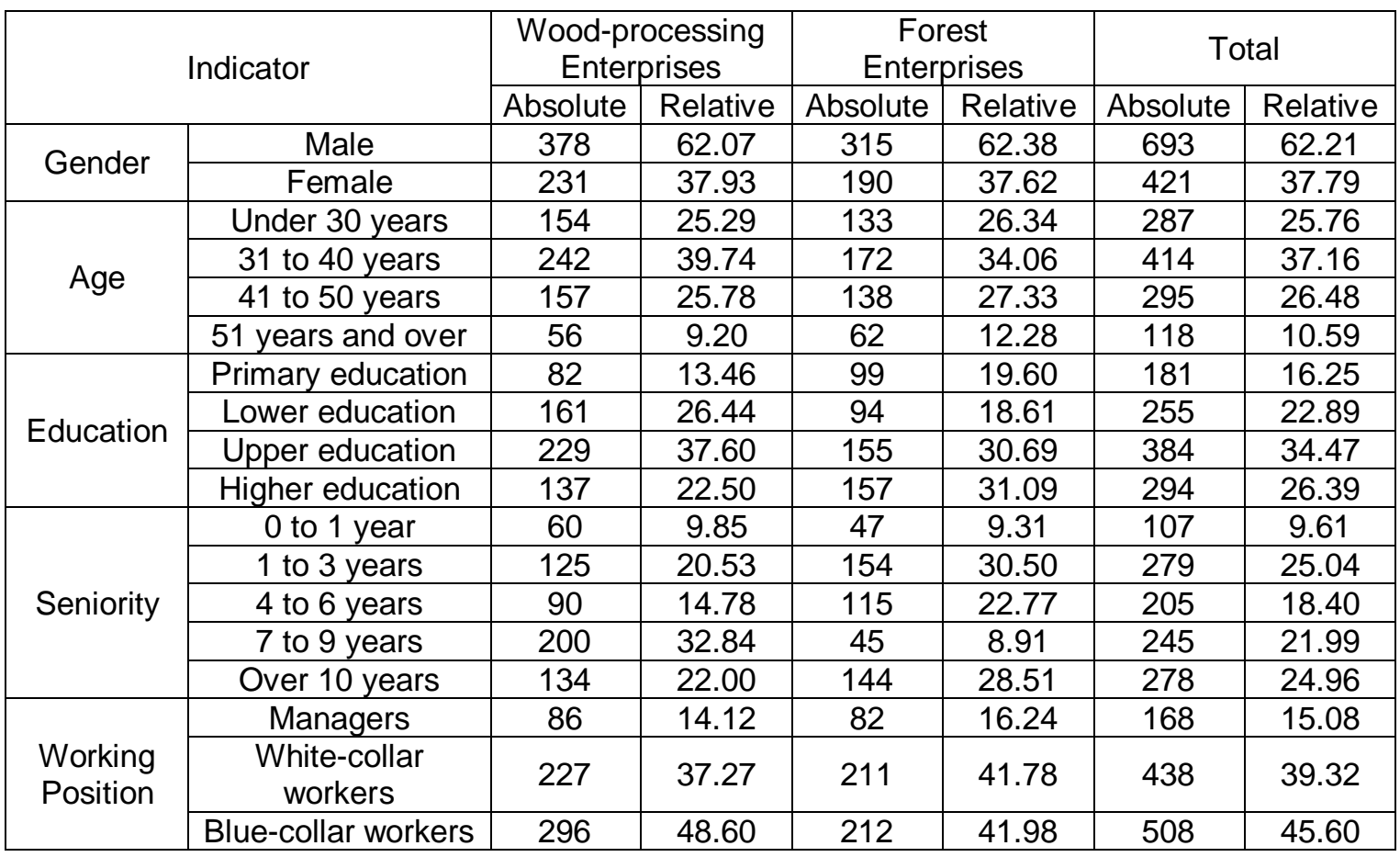

\section{Methods of Research Evaluation}

The second part of the questionnaire was based on the Organizational Culture Assessment Instrument (OCAI) questionnaire methodology based on the Competing Values Framework (Quinn and Rohrbaugh 1983). The framework is the synthesis of organizational theories assuming that the majority of organizations can be characterized using two dimensions. Each dimension represents alternative approaches to the basics, and all organizations must solve them to be able to operate (Denison and Spreitzer 1991). The two basic dimensions of the model are flexibility $v s$. control and internal $v s$. external focus. Four types of cultures have been created using their combination: clan culture, adhocratic, hierarchical, and market (Cameron and Quinn 2006). The clan corporate culture corresponds to alternative A. Enterprises carrying this type of corporate culture employed team thinking, employee development programs in their management, and they focused on creating a friendly work environment. The adhocratic corporate culture is another type of 
corporate culture corresponding with alternative B. This corporate culture supports the creation of work teams for the purpose of solving some specific goal or a task. The market corporate culture is the third type of corporate culture, which corresponds to alternative $\mathrm{C}$. Its operation is based on market mechanisms. For alternative $\mathrm{C}$ the final results, competitiveness, and productivity are the deciding goals. Hierarchical corporate culture (alternative D) is the last type. It is characterized by a formalized and structuralized work environment, which emphasizes procedures and regulations. Formal rules are the binding element. Leading employees are good coordinators and organizers. Smooth organization operation, its stability, and efficiency were the decisive factors.

The type of corporate culture was determined by six components (Dominant Characteristics, Organizational Leadership, Management of Employees, Organization Glue, Strategic Emphases, and Criteria of Success). Each of the six components presented in Table 2 was examined on the four alternatives (Cameron et al. 2006).

Table 2. The Organizational Culture Assessment Instrument Questionnaire Methodology

\begin{tabular}{|c|c|}
\hline \multicolumn{2}{|r|}{ 1. Dominant Characteristics } \\
\hline Alternative $\mathrm{A}$ & $\begin{array}{c}\text { The organization is a very personal place. It is like an extended family. People } \\
\text { seem to share a lot of personal information and features. }\end{array}$ \\
\hline Alternative B & $\begin{array}{c}\text { The organization is a very dynamic entrepreneurial place. People are willing to } \\
\text { stick their necks out and take risks. }\end{array}$ \\
\hline Alternative $\mathrm{C}$ & $\begin{array}{l}\text { The organization is very results-oriented. A major concern is getting the job } \\
\text { done. People are very competitive and achievement-oriented. }\end{array}$ \\
\hline Alternative D & $\begin{array}{c}\text { The organization is a very controlled and structured place. Formal procedures } \\
\text { generally govern what people do. }\end{array}$ \\
\hline \multicolumn{2}{|r|}{ 2. Organizational Leadership } \\
\hline Alternative A & $\begin{array}{c}\text { The leadership in the organization is generally considered to exemplify } \\
\text { mentoring, facilitating, or nurturing. }\end{array}$ \\
\hline Alternative B & $\begin{array}{l}\text { The leadership in the organization is generally considered to exemplify } \\
\text { entrepreneurship, innovation, or risk taking. }\end{array}$ \\
\hline Alternative $\mathrm{C}$ & $\begin{array}{c}\text { The leadership in the organization is generally considered to exemplify a no- } \\
\text { nonsense, aggressive, or results-oriented focus. }\end{array}$ \\
\hline Alternative D & $\begin{array}{c}\text { The leadership in the organization is generally considered to exemplify } \\
\text { coordinating, organizing, or smooth-running efficiency. }\end{array}$ \\
\hline \multicolumn{2}{|r|}{ 3. Management of Employees } \\
\hline Alternative A & $\begin{array}{l}\text { The management style in the organization is characterized by teamwork, } \\
\text { consensus, and participation. }\end{array}$ \\
\hline Alternative B & $\begin{array}{c}\text { The management style in the organization is characterized by individual risk } \\
\text { taking, innovation, freedom, and uniqueness. }\end{array}$ \\
\hline Alternative C & $\begin{array}{c}\text { The management style in the organization is characterized by hard-driving } \\
\text { competitiveness, high demands, and achievement. }\end{array}$ \\
\hline Alternative D & $\begin{array}{l}\text { The management style in the organization is characterized by security of } \\
\text { employment, conformity, predictability, and stability in relationships. }\end{array}$ \\
\hline \multicolumn{2}{|r|}{ 4. Organization Glue } \\
\hline Alternative $\mathrm{A}$ & $\begin{array}{l}\text { The glue that holds the organization together is loyalty and mutual trust. } \\
\text { Commitment to this organization runs high. }\end{array}$ \\
\hline Alternative B & $\begin{array}{l}\text { The glue that holds the organization together is commitment to innovation and } \\
\text { development. There is an emphasis on being on the cutting edge. }\end{array}$ \\
\hline Alternative C & $\begin{array}{l}\text { The glue that holds the organization together is an emphasis on achievement } \\
\text { and goal accomplishment. }\end{array}$ \\
\hline Alternative D & $\begin{array}{c}\text { The glue that holds the organization together is formal rules and policies. } \\
\text { Maintaining a smooth-running organization is important. }\end{array}$ \\
\hline
\end{tabular}

Lorincová et al. (2020). "Wood corporate culture," BioResources 15(2), 3320-3343. 


\begin{tabular}{|l|c|}
\hline \multicolumn{2}{|c|}{ 5. Strategic Emphases } \\
\hline Alternative A & $\begin{array}{c}\text { The organization emphasizes human development. High trust, openness, and } \\
\text { participation persist. }\end{array}$ \\
\hline Alternative B & $\begin{array}{c}\text { The organization emphasizes acquiring new resources and creating new } \\
\text { challenges. Trying new things and prospecting for opportunities are valued. }\end{array}$ \\
\hline Alternative C & $\begin{array}{c}\text { The organization emphasizes competitive actions and achievement. Hitting } \\
\text { stretch targets and winning in the marketplace are dominant. }\end{array}$ \\
\hline Alternative D & $\begin{array}{c}\text { The organization emphasizes permanence and stability. Efficiency, control, and } \\
\text { smooth operations are important. }\end{array}$ \\
\hline Alternative A & $\begin{array}{c}\text { The organization defines success on the basis of development of human } \\
\text { resources, teamwork, employee commitment, and concern for people. }\end{array}$ \\
\hline Alternative B & $\begin{array}{c}\text { The organization defines success on the basis of having the most unique or } \\
\text { newest products. It is a product leader and innovator. }\end{array}$ \\
\hline Alternative C & $\begin{array}{c}\text { The organization defines success on the basis of winning in the marketplace } \\
\text { and outpacing the competition. Competitive market leadership is a key. }\end{array}$ \\
\hline Alternative D & $\begin{array}{r}\text { The organization defines success on the basis of efficiency. Dependable } \\
\text { delivery, smooth scheduling, and low-cost production are critical. }\end{array}$ \\
\hline
\end{tabular}

Source: Cameron et al. 2006

The questionnaire was completed by the respondents by their dividing 100 points based on the type of corporate culture they prefer. According to the OCAI methodology, it was possible to determine the type of corporate culture by averaging individual scores. The results were evaluated using the Statistica 12.0 software (Dell, Oklahoma City, OK, USA). Basic sample sets were described using descriptive statistics and variance analysis. Location as a feature with other values concentrated around were used to achieve explicit mutual comparison of statistical sample sets (wood-processing and forest enterprises) was used. The location was measured using the arithmetic mean. Variability characteristics determining the difference in the values of the statistical set were used as well. They are an important factor in the case of comparing the sets with the characteristics of location identical. Variability was measured using the standard deviation. Dispersion analysis (ANOVA) was another statistical method used. It is a parametric statistical method created to compare the groups, more than two, mutually. Sources of variance of linear statistical methods are analyzed using ANOVA. It is based on dividing the total variance of the population. In the practice, factors affecting the behavior of specific mathematical quantity can be defined or detailed comparison of populations can be carried out this way. The Ttest was also used in the research. It is used to test hypotheses to define the differences in collected data of two analyzed sample sets. The probability to achieve the value of the test statistics higher or equal to the real value when the null hypothesis is accepted is expressed by the p-value. Following the p-value which is the lowest level of significance, the null hypothesis can be rejected. In the case of our research, the value of test criterion was 0.05 . Using the t-test, the hypotheses were verified:

WH1: It is supposed that there are statistically significant differences in individual components of corporate culture between wood-processing and forest enterprises.

WH2: It is supposed that there are statistically significant differences in a type of corporate culture between wood-processing and forest enterprises. 


\section{RESULTS AND DISCUSSIONS}

The area of dominant characteristics was the first examined area. The measured average values of individual alternatives are presented in Table 3 and Fig. 1. Following the results, it was indicated that the alternative A achieved the highest average values in woodprocessing $(\bar{X}=35.250)$ and forest $(\bar{X}=32.44)$ enterprises. Alternative A was preferred by the employees working in both types of enterprises. Managers must be focused on creating a very personal environment. The working environment should resemble a large family, where people are often in mutual contact and they have a lot in common.

Table 3. Comparison of Dominant Characteristics in Wood-processing Enterprises and Forest Enterprises

\begin{tabular}{|c|c|c|c|c|c|c|c|}
\hline \multirow{2}{*}{ Indicator } & \multicolumn{2}{|c|}{ Average } & \multicolumn{2}{|c|}{ Standard Deviation } & \multirow{2}{*}{ t-test } & \multirow{2}{*}{$\begin{array}{c}\text { Degree } \\
\text { of } \\
\text { Freedom }\end{array}$} & \multirow{2}{*}{$\begin{array}{c}\mathrm{p}- \\
\text { value }\end{array}$} \\
\hline & WPE & FE & WPE & FE & & & \\
\hline Alternative A & 35.250 & 32.444 & 25.434 & 24.130 & 1.313 & 779.000 & 0.189 \\
\hline Alternative B & 19.333 & 14.694 & 16.310 & 14.015 & 3.745 & 337.118 & 0.000 \\
\hline Alternative C & 27.068 & 23.161 & 23.087 & 19.822 & 2.230 & 337.376 & 0.026 \\
\hline Alternative D & 18.349 & 29.700 & 17.165 & 27.810 & -5.188 & 221.316 & 0.000 \\
\hline
\end{tabular}

Note: Significant differences are in bold; $p$-value $<0.05$

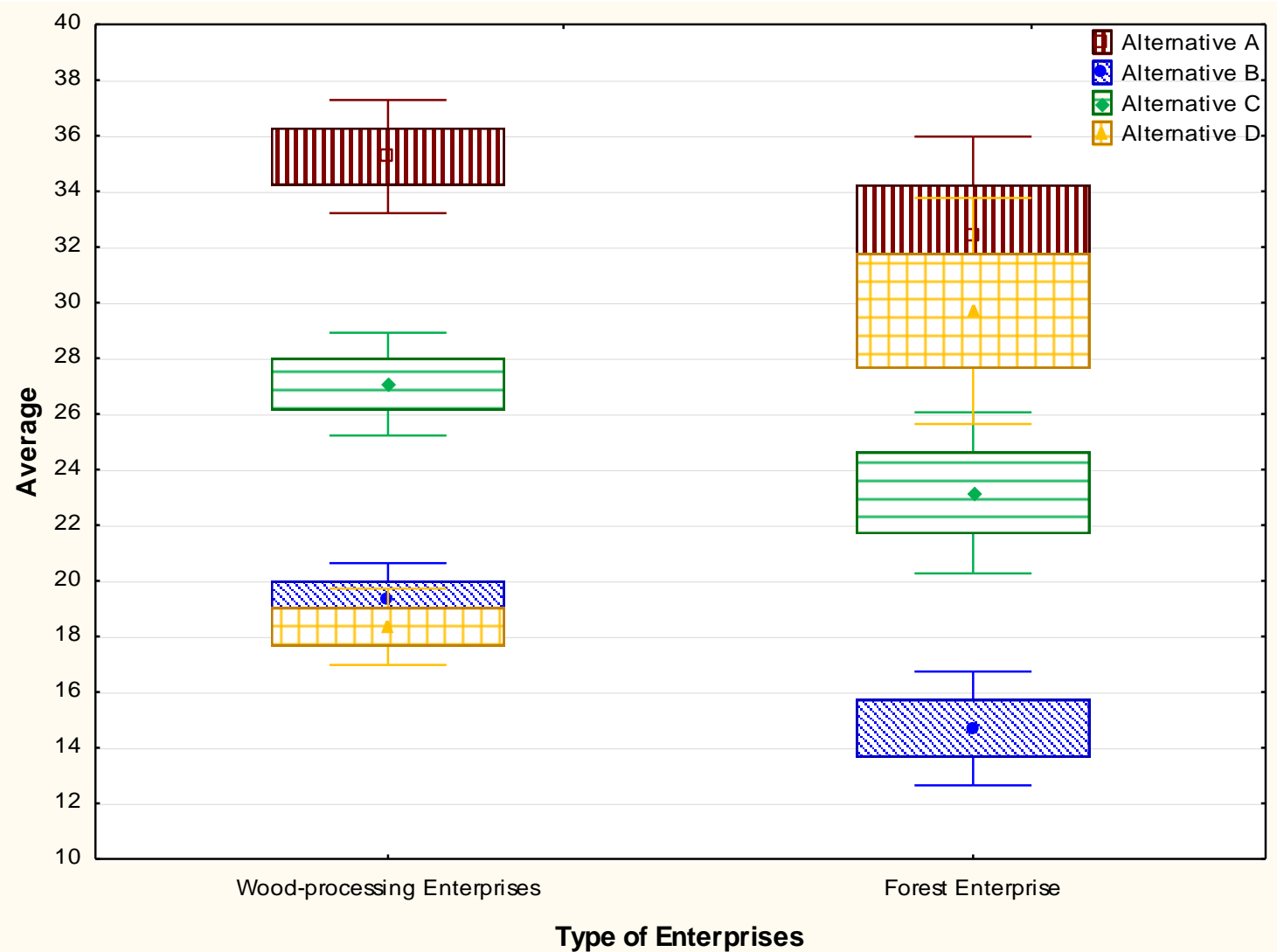

Fig. 1. Comparison of dominant characteristics in wood-processing enterprises and forest enterprises 
The achieved results were confirmed also by the $\mathrm{p}$-value $(\mathrm{p}=0.189)$, according to which in alternative A there were no significant differences in the perception of preferred level of dominant characteristics for both groups of employees.

The results presented in Table 4 and Fig. 2 indicate that in the perception of organizational leadership, both groups of respondents assigned higher values to alternative D.

Table 4. Comparison of Organizational Leadership in Wood-processing Enterprises and Forest Enterprises

\begin{tabular}{|c|c|c|c|c|c|c|c|}
\hline \multirow{2}{*}{ Indicator } & \multicolumn{2}{|c|}{ Average } & \multicolumn{2}{c|}{ Standard Deviation } & t-test & $\begin{array}{c}\text { Degree } \\
\text { of } \\
\text { Freedom }\end{array}$ & $\begin{array}{c}\mathrm{p}- \\
\text { value }\end{array}$ \\
\cline { 2 - 5 } & WPE & FE & WPE & FE & & $\mathbf{2 1 . 5 8}$ & $\mathbf{0 . 0 0 0}$ \\
\hline Alternative A & $\mathbf{2 8 . 5 6 1}$ & $\mathbf{2 1 . 6 1 1}$ & $\mathbf{2 4 . 2 8 7}$ & $\mathbf{1 8 . 5 8}$ & $\mathbf{4 . 0 8 1}$ & $\mathbf{3 7 9 . 3 1 6}$ & $\mathbf{0 . 0 0 0}$ \\
\hline Alternative B & 27.913 & 26.639 & 22.529 & 20.847 & 0.677 & 779.000 & 0.499 \\
\hline Alternative C & 14.805 & 13.694 & 15.536 & 15.294 & 0.845 & 779.000 & 0.399 \\
\hline Alternative D & $\mathbf{2 8 . 7 2 0}$ & $\mathbf{3 8 . 0 5 6}$ & $\mathbf{2 3 . 8 5 6}$ & $\mathbf{2 1 . 7 9 4}$ & $\mathbf{- 4 . 6 9 6}$ & $\mathbf{7 7 9 . 0 0 0}$ & $\mathbf{0 . 0 0 0}$ \\
\hline
\end{tabular}

Note: Significant differences are in bold; $p$-value $<0.05$

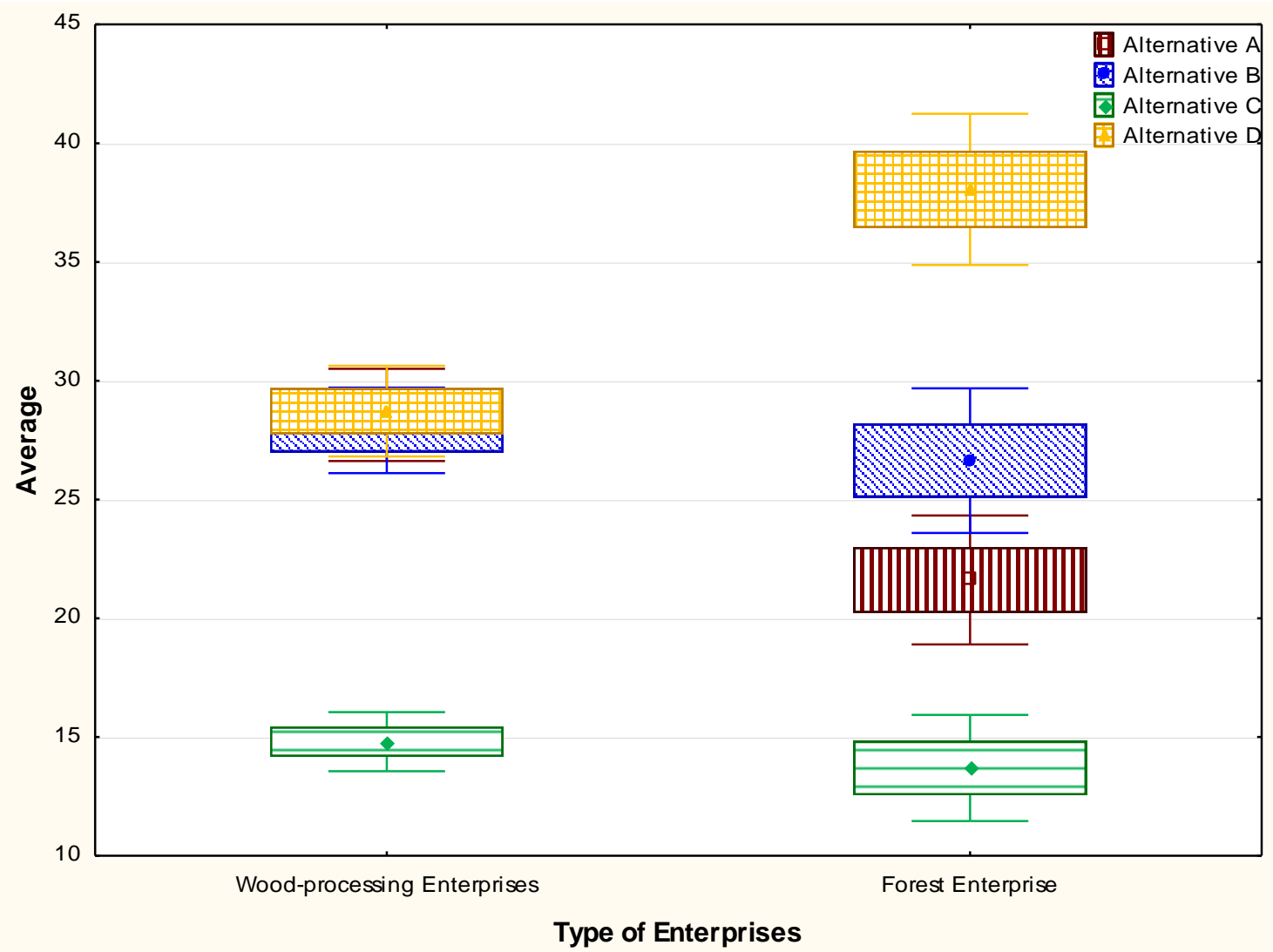

Fig. 2. Comparison of organizational leadership in wood-processing enterprises and forest enterprises

Leadership in wood-processing enterprises and forest enterprises should be considered a demonstration of cooperative, organized, and smooth operating performance. 
Despite this, the presence of significant differences in alternative $\mathrm{D}$ among the opinions of the respondents $(\mathrm{p}=0.000)$ was confirmed by the t-test. Hypothesis WH1 was confirmed.

Next, the object of examination was management of employees. The highest average score achieved by alternative A is presented in Table 5 and Fig. 3. Teamwork and cooperation should be a key factor in managing employees. Significant differences in the opinions of respondents in this alternative $(\mathrm{p}=0.314)$ was not confirmed by the t-test.

Table 5. Comparison of Management of Employees in Wood-processing Enterprises and Forest Enterprises

\begin{tabular}{|c|c|c|c|c|c|c|c|}
\hline \multirow{2}{*}{ Indicator } & \multicolumn{2}{|c|}{ Average } & \multicolumn{2}{|c|}{ Standard Deviation } & \multirow[b]{2}{*}{ t-test } & \multirow{2}{*}{$\begin{array}{c}\text { Degree } \\
\text { of } \\
\text { Freedom }\end{array}$} & \multirow{2}{*}{$\begin{array}{c}\mathrm{p}- \\
\text { value }\end{array}$} \\
\hline & WPE & FE & WPE & FE & & & \\
\hline Alternative A & 38.717 & 40.694 & 26.307 & 22.051 & -1.007 & 345.411 & 0.314 \\
\hline Alternative B & 19.950 & 15.139 & 18.915 & 13.406 & 3.811 & 412.338 & 0.000 \\
\hline Alternative C & 14.744 & 12.694 & 16.168 & 15.045 & 1.515 & 779.000 & 0.130 \\
\hline Alternative D & 26.589 & 31.472 & 21.617 & 16.660 & -3.206 & 376.463 & 0.001 \\
\hline
\end{tabular}

Note: Significant differences are in bold; $p$-value $<0.05$

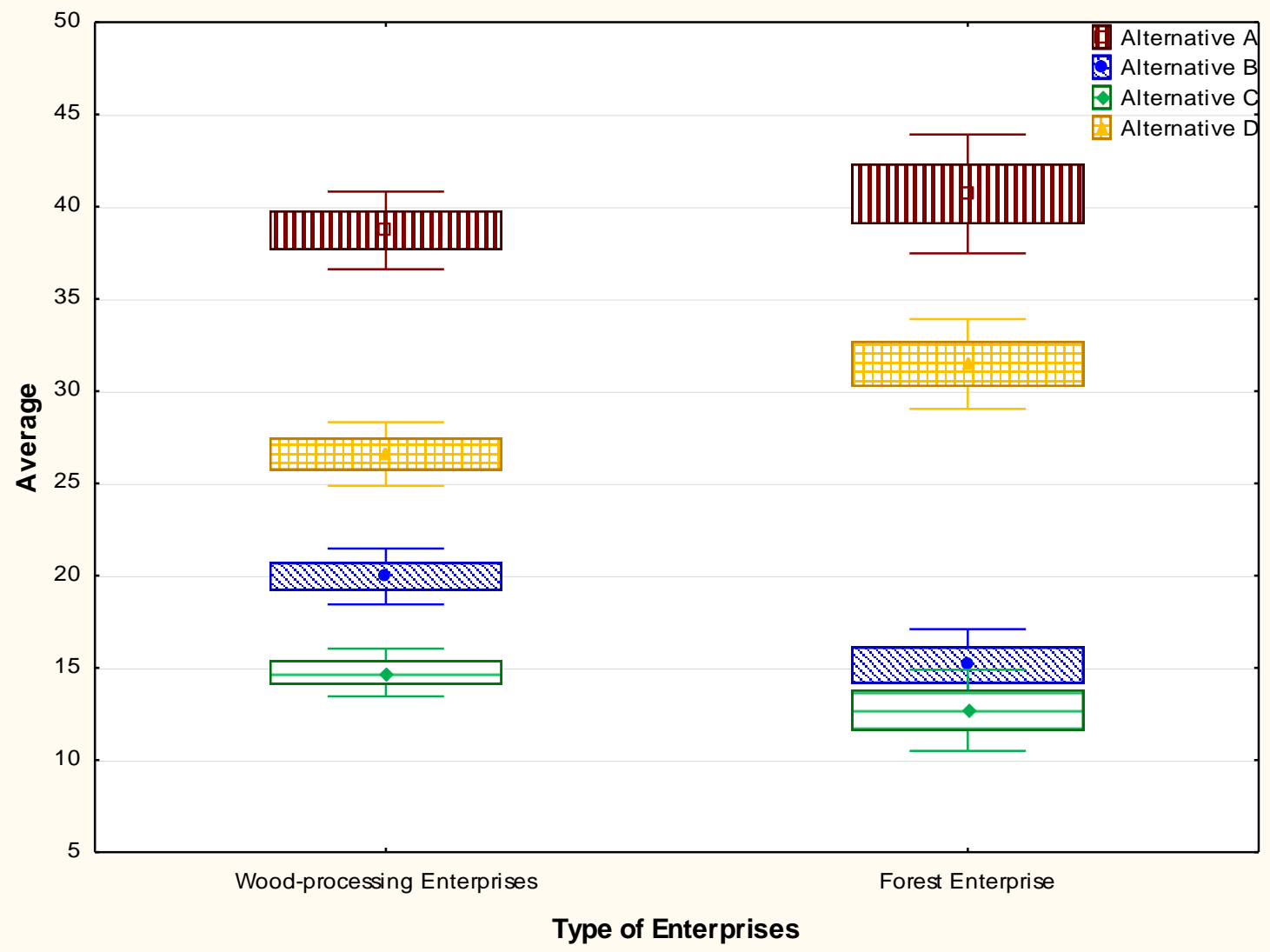

Fig. 3. Comparison of management of employees in wood-processing enterprises and forest enterprises

The results in Table 6 and Fig. 4 on the field of organization glue show that the employees of wood-processing $(X=34.303)$ and forest enterprises $(X=32.278)$ agreed 
with each other. The highest average score to alternative A was assigned. Loyalty, mutual trust, and high devotion to the enterprise should be the biggest glue of the enterprise. The presence of statistically significant differences in the opinions of employees of woodprocessing and forest enterprises in this alternative $(\mathrm{p}=0.259)$ was not supported by statistical testing.

Table 6. Comparison of Organization Glue in Wood-processing Enterprises and Forest Enterprises

\begin{tabular}{|c|c|c|c|c|c|c|c|}
\hline \multirow{2}{*}{ Indicator } & \multicolumn{2}{|c|}{ Average } & \multicolumn{2}{|c|}{ Standard Deviation } & \multirow{2}{*}{ t-test } & \multirow{2}{*}{$\begin{array}{c}\text { Degree } \\
\text { of } \\
\text { Freedom }\end{array}$} & \multirow{2}{*}{$\begin{array}{c}\mathrm{p}- \\
\text { value }\end{array}$} \\
\hline & WPE & FE & WPE & FE & & & \\
\hline Alternative $\mathrm{A}$ & 34.303 & 32.278 & 25.401 & 19.586 & 1.131 & 376.283 & 0.259 \\
\hline Alternative B & 22.364 & 20.172 & 19.155 & 16.238 & 1.522 & 341.594 & 0.129 \\
\hline Alternative C & 21.351 & 26.000 & 18.997 & 17.372 & -2.936 & 779.000 & 0.003 \\
\hline Alternative D & 21.982 & 21.550 & 19.880 & 18.442 & 0.260 & 779.000 & 0.795 \\
\hline
\end{tabular}

Note: Significant differences are in bold; $p$-value $<0.05$

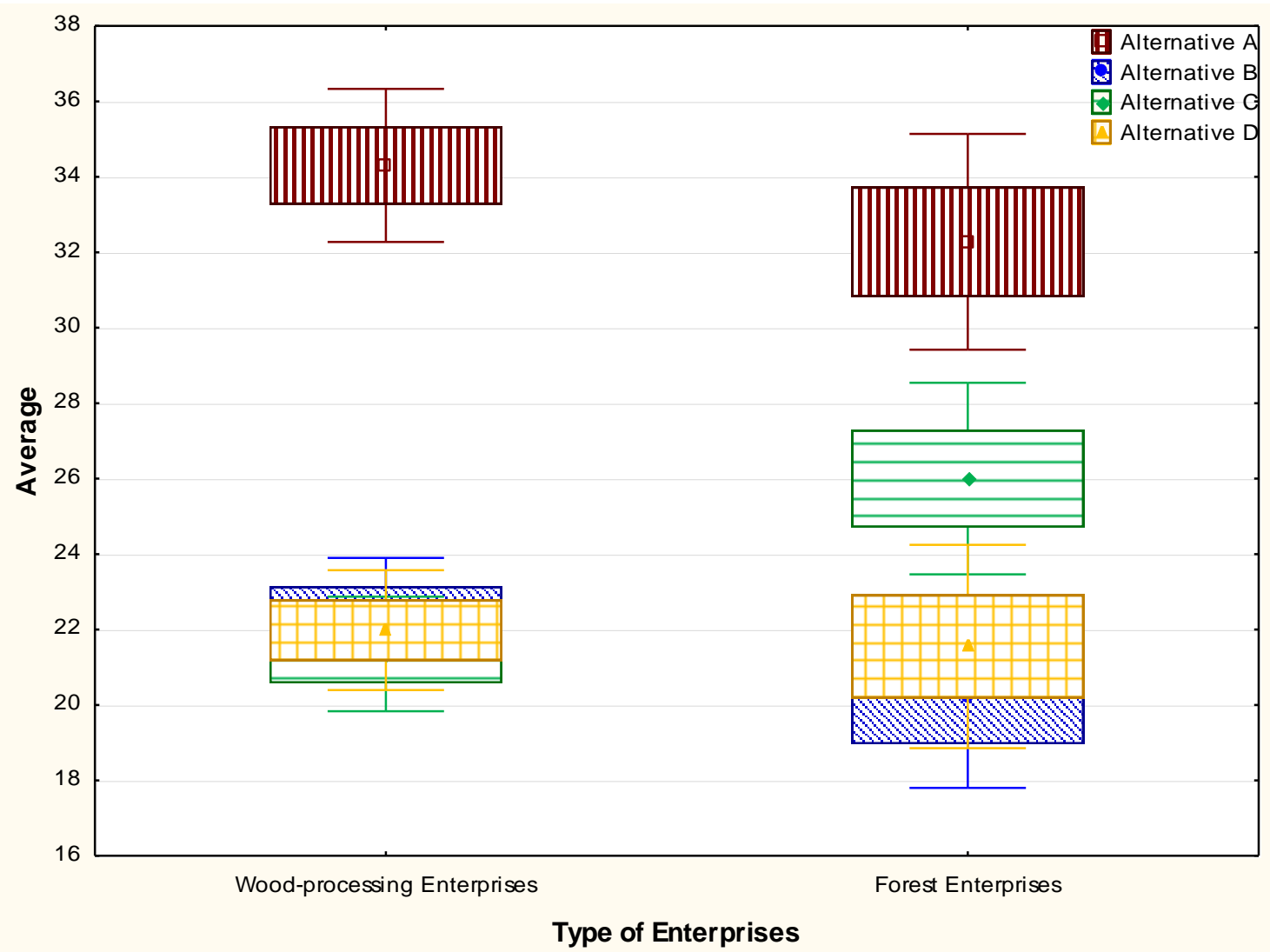

Fig. 4. Comparison of organization glue in wood-processing enterprises and forest enterprises

There was a mutual consensus in the examination of strategic emphases. Alternative $\mathrm{A}$ as the most preferred cooperate culture among the employees of woodprocessing $(X=31.323)$ and forest $(X=33.278)$ enterprises is shown in Table 7 and Fig. 5 . The strategies of the enterprises should be focused on human development, high level of 
trust, openness, and retention of employees. In the preferred alternative, there were no statistically significant differences in the opinions of the respondents $(p=0.265)$.

Table 7. Comparison of Strategic Emphases in Wood-processing Enterprises and Forest Enterprises

\begin{tabular}{|c|c|c|c|c|c|c|c|}
\hline \multirow{2}{*}{ Indicator } & \multicolumn{2}{|c|}{ Average } & \multicolumn{2}{|c|}{ Standard Deviation } & \multirow{2}{*}{ t-test } & \multirow{2}{*}{$\begin{array}{c}\begin{array}{c}\text { Degree } \\
\text { of }\end{array} \\
\text { Freedom }\end{array}$} & \multirow{2}{*}{$\begin{array}{c}p- \\
\text { value }\end{array}$} \\
\hline & WPE & FE & WPE & FE & & & \\
\hline Alternative A & 31.323 & 33.278 & 22.867 & 19.862 & -1.117 & 333.636 & 0.265 \\
\hline Alternative B & 23.251 & 21.694 & 17.639 & 17.458 & 1.041 & 779.000 & 0.298 \\
\hline Alternative C & 24.487 & 20.861 & 19.958 & 14.835 & 2.640 & 391.372 & 0.009 \\
\hline Alternative D & 20.939 & 24.167 & 18.801 & 22.100 & -1.776 & 261.347 & 0.077 \\
\hline
\end{tabular}

Note: Significant differences are in bold; $p$-value $<0.05$

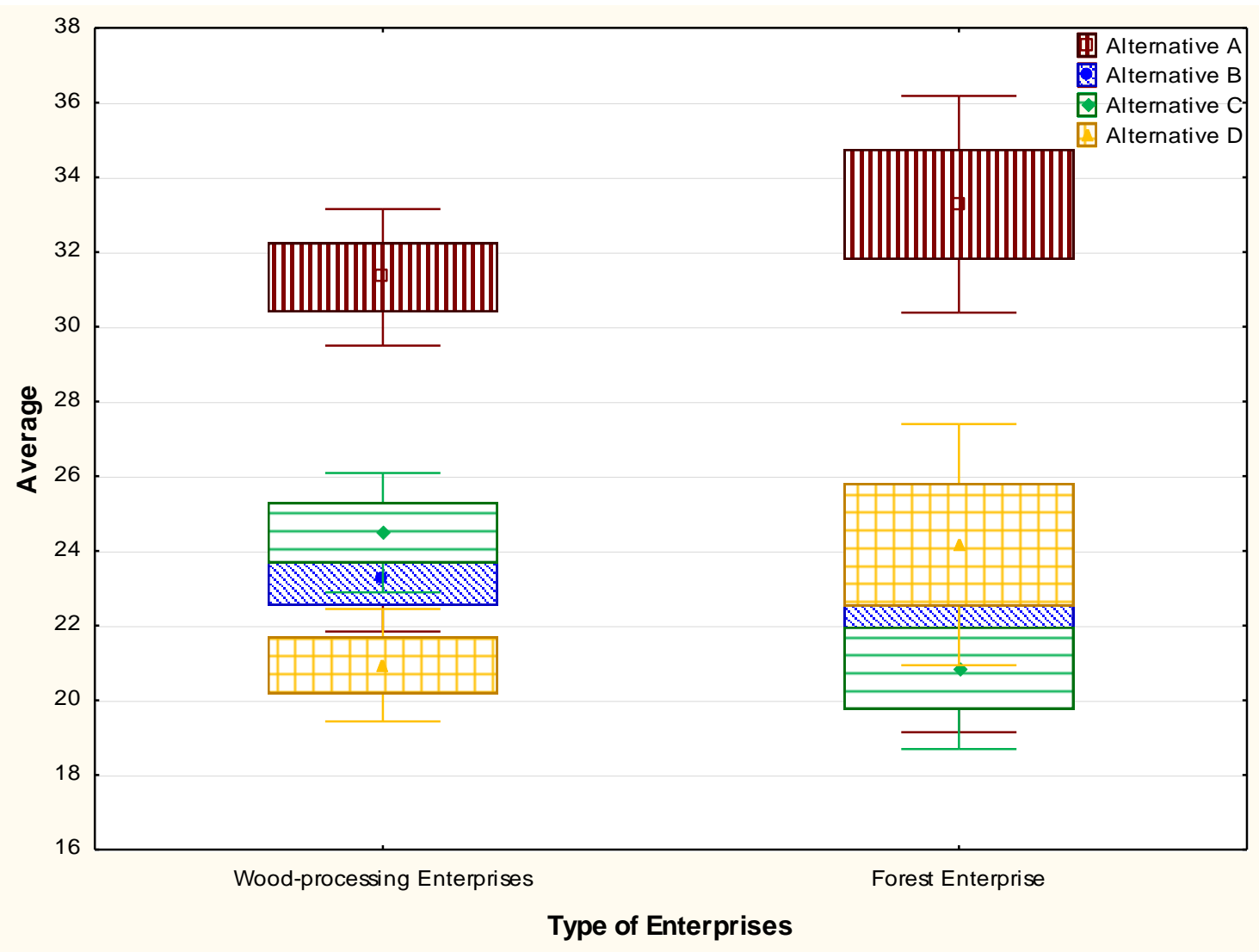

Fig. 5. Comparison of strategic emphases in wood-processing enterprises and forest enterprises

The last examined area was the area of criteria of success. The results are shown in Table 8 and Fig. 6. The employees of wood-processing enterprises considered alternative A to be the dominant $(X=31.966)$. The success of wood-processing enterprises should be built on the development of human resources, teamwork, employment agreement, and interest in people. Compared to the employees of forest enterprises, there were no statistically significant differences in the opinions of the respondents $(p=0.383)$. The employees of the forest enterprises considered the alternative $D$ to be the most important $(X=34.333)$. For employees of the wood-processing enterprises, this was the second most 
important alternative. The success of forest enterprises should be built on the performance, reliability of the deliveries, mastering logistics, and low-cost production. In alternative D, the existence of significant differences in the opinions of the respondents $(p=0.000)$ was demonstrated by the t-test. Hypothesis WH1 was confirmed.

Table 8. Comparison of Criteria of Success in Wood-processing Enterprises and Forest Enterprises

\begin{tabular}{|c|c|c|c|c|c|c|c|}
\hline \multirow{2}{*}{ Indicator } & \multicolumn{2}{|c|}{ Average } & \multicolumn{2}{|c|}{ Standard Deviation } & \multirow{2}{*}{ t-test } & \multirow{2}{*}{$\begin{array}{c}\text { Degree } \\
\text { of } \\
\text { Freedom }\end{array}$} & \multirow{2}{*}{$\begin{array}{c}\mathrm{p}- \\
\text { value }\end{array}$} \\
\hline & WPE & FE & WPE & FE & & & \\
\hline Alternative $\mathrm{A}$ & 31.966 & 30.500 & 23.527 & 18.491 & 0.873 & 368.780 & 0.383 \\
\hline Alternative B & 21.362 & 15.778 & 19.223 & 14.956 & 4.097 & 372.721 & 0.000 \\
\hline Alternative $\mathrm{C}$ & 19.569 & 19.389 & 17.540 & 19.935 & 0.109 & 267.348 & 0.913 \\
\hline Alternative D & 27.103 & 34.333 & 22.740 & 22.642 & -3.746 & 779.000 & 0.000 \\
\hline
\end{tabular}

Note: Significant differences are in bold; $p$-value $<0.05$

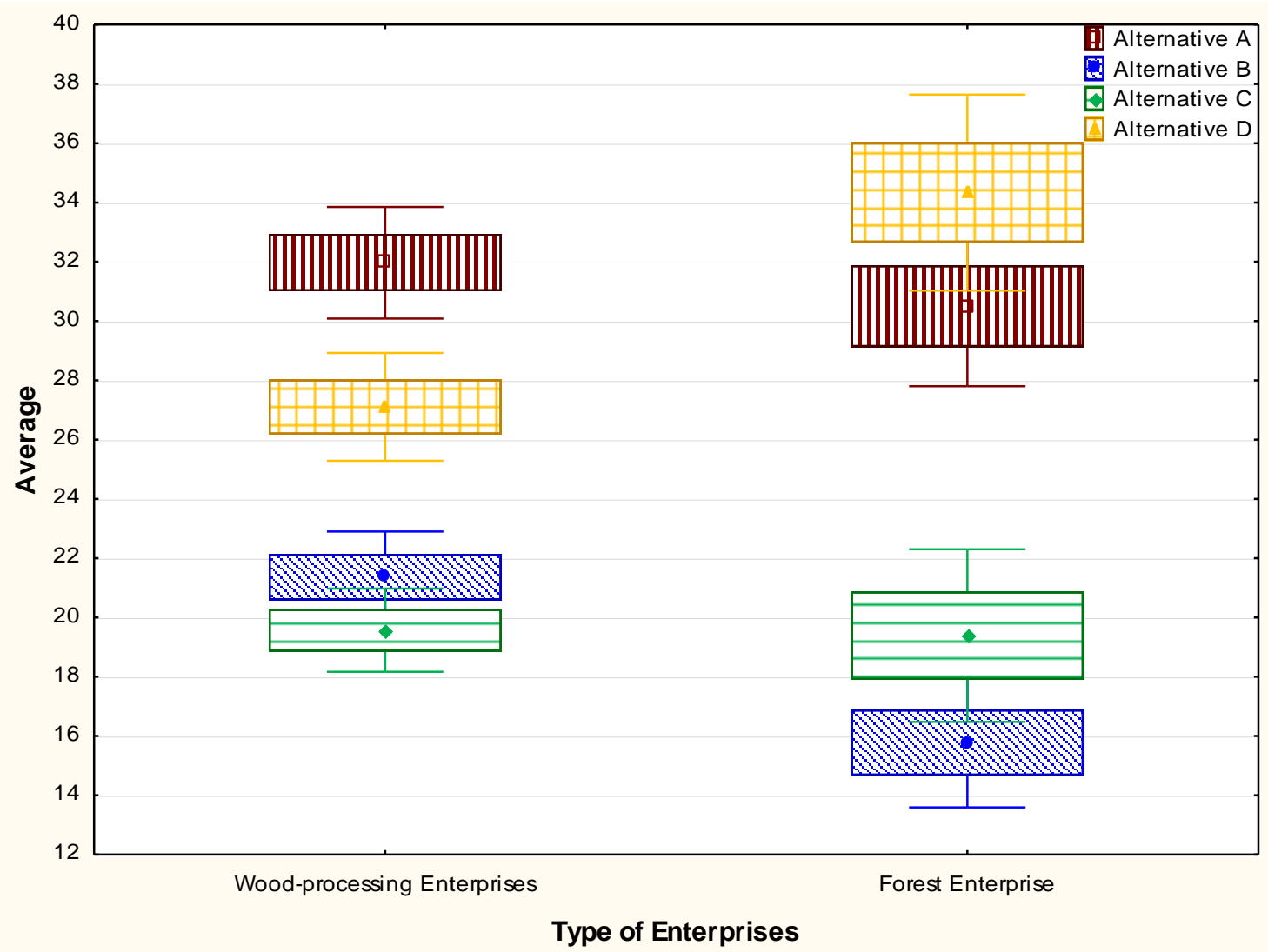

Fig. 6. Comparison of criteria of success in wood-processing enterprises and forest enterprises

In terms of the methodology of Cameron and Quinn (2006), the type of corporate culture was defined by averaging the individual scores. The results are shown in Table 9 and Fig. 7. The employees of wood-processing $(X=33.353)$ and forest $(X=31.801)$ enterprises were in agreement. They preferred to use the clan corporate culture in enterprises. Managers should focus on creating a very pleasant workplace, where people share a lot of personal information like a large family. The leaders of the organization 
should be considered to be mentors and parents. The organization should be united through loyalty and tradition. Teamwork and cooperation should be typical. In testing the clan corporate culture, the presence of statistically significant differences in the opinions of the respondents $(\mathrm{p}=0.043)$ was not supported by the t-test. Hypothesis WH2 was not confirmed.

Table 9. Comparison of Corporate Culture in Wood-processing Enterprises and Forest Enterprises

\begin{tabular}{|c|c|c|c|c|c|c|c|}
\hline \multirow{2}{*}{ Corporate Culture } & \multicolumn{2}{|c|}{ Average } & \multicolumn{2}{|c|}{ Standard Deviation } & \multirow{2}{*}{$\begin{array}{c}\text { Degree } \\
\text { of }\end{array}$} & p-value \\
\cline { 2 - 5 } & WPE & FE & WPE & FE & & Freedom & \\
\hline Clan Culture & 33.353 & 31.801 & 24.859 & 21.252 & 2.022 & 2041.874 & 0.043 \\
\hline Adhocracy Culture & $\mathbf{2 2 . 3 6 2}$ & $\mathbf{1 9 . 0 1 9}$ & $\mathbf{1 9 . 2 5 1}$ & $\mathbf{1 6 . 8 6 4}$ & $\mathbf{5 . 5 2 5}$ & $\mathbf{1 9 9 4 . 6 0 0}$ & $\mathbf{0 . 0 0 0}$ \\
\hline Market Culture & 20.337 & 19.300 & 19.260 & 17.803 & 1.648 & 1898.270 & 0.100 \\
\hline Hierarchy Culture & $\mathbf{2 3 . 9 4 7}$ & $\mathbf{2 9 . 8 8 0}$ & $\mathbf{2 1 . 1 2 3}$ & $\mathbf{2 2 . 5 2 9}$ & $\mathbf{- 7 . 6 9 9}$ & $\mathbf{1 6 8 6 . 9 9 5}$ & $\mathbf{0 . 0 0 0}$ \\
\hline
\end{tabular}

Note: Significant differences are in bold; $p$-value $<0.05$

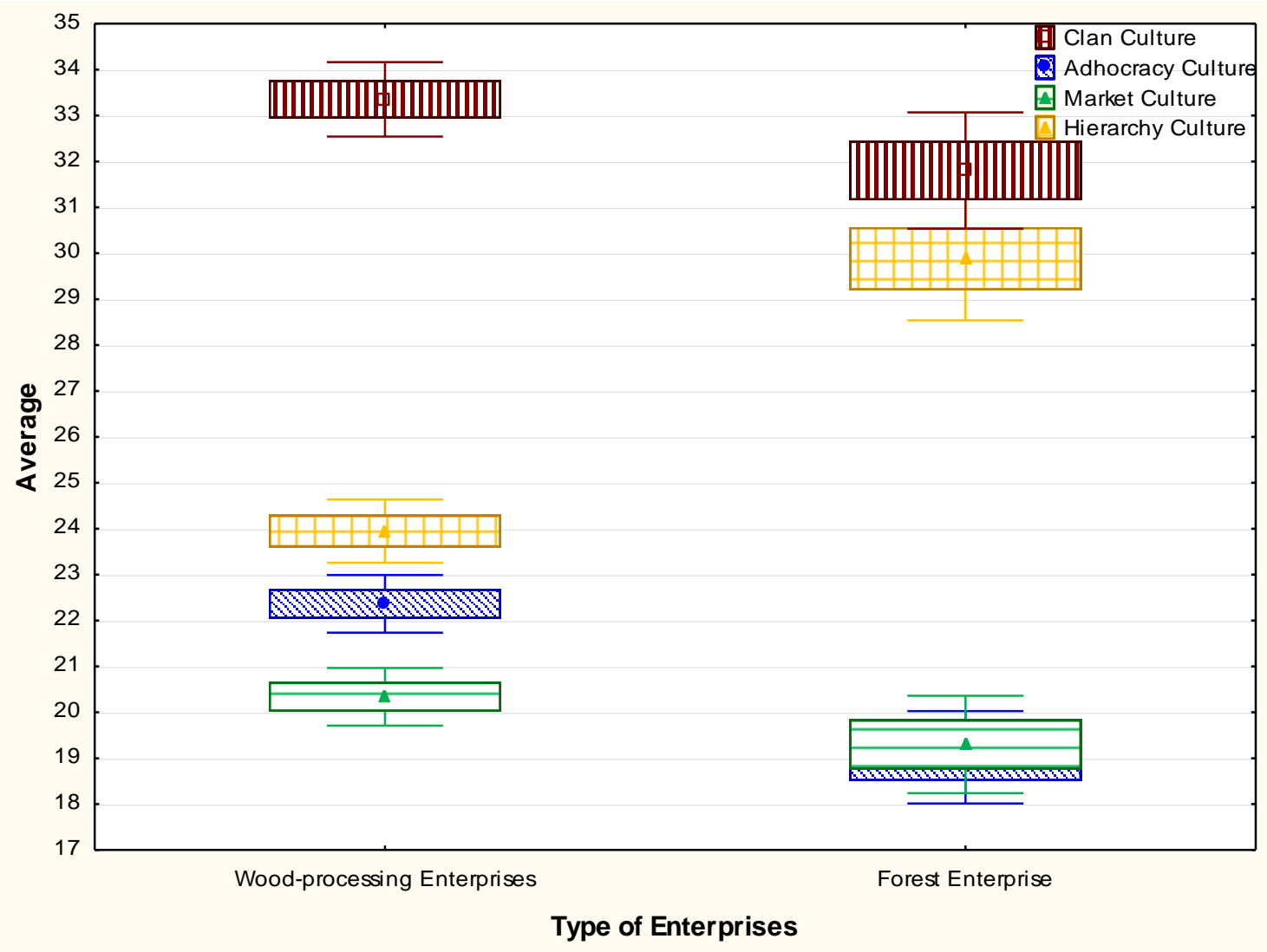

Fig. 7. Comparison of corporate culture in wood-processing enterprises and forest enterprises

The comparable survey introduced in the OCAI methodology was conducted in 236 medium and large enterprises in the Slovak Republic. The research results showed that for the most part, a hierarchical corporate structure dominated in $37.29 \%$ of enterprises, which was typically shown by its centralized observance of rules, regulations, norms, principles, 
and procedures, which causes severe bureaucracy (Schimmoeller 2010; Vetraková and Smerek 2015). The implementation of hierarchical corporate culture has a negative impact on the enterprise at the time of introducing the changes to the organization, because these organizations react efficiently and effectively only to known situations and they have a problem dealing with change. In this context, the wood-processing and forest enterprises involved in this research could be evaluated positively, because the clan culture is dominating in these enterprises. The results of this presented research showed that the enterprises were still inward-oriented, but the clan culture supported necessary flexibility for sustaining competitiveness in today's turbulent business environment. The clan culture also supported changes in how people think, and it provided greater space for the development of human resources and cooperation. Clan corporate culture is considered the best type of corporate culture in wood-processing and forest enterprise because it is focused on the development of each person. Great attention should be paid to coherence, morale, and the working environment. Success should be measured in relation to the internal environment and care for the employees because employees represent a strategic tool in the management of many companies.

The results of the current research have also confirmed the hypothesis that there were significant differences between the wood-processing and the forest enterprises in individual components of corporate culture, which were identified in the previous research as the differences in opinions, values, convictions, attitudes, preferences, or goals of individual generations (Santos and Cox 2000; Bauerlein 2009; Hershatter and Epstein 2010; Ng and Schweitzer 2010; McCready 2011; De Waal et al. 2017). All typologies of corporate culture, just like the OCAI questionnaire methodology used by this research, have a complicated content of social reality of the organization and they facilitate the understanding of major characteristics, which create differences between the organizations. Although a number of them were created over the past decades, given the complexity and multidimensional nature of the examined phenomenon, none of them were and cannot be an exhaustive typology; however, each of them offered certain aspects of corporate culture understood in a certain context. In the current case, the context was dimensions of flexibility vs. control and internal $v s$. external focus according to the model of Cameron and Quinn (2006). It is important to keep in mind the other sides of typologies, i.e. their bottlenecks and limitations, which is the fact that each typology is a simplification of reality, because any organization cannot be simply assigned to a certain type, because for the most part they contain clear features of several cultures (Lukášová and Nový 2004). Under some circumstance, the corporate culture can be weak and diffusive. In this case, it is probably impossible to identify the content based on the typologies (Lukášová and Nový 2004). Lastly, it is necessary to add to the generally valid limitations the limiting circumstance of typology, because all listed typologies were developed in different cultural and market environments to that of the Slovak Republic (Stacho and Stachova 2015). The authors agreed with some experts who see the reasons for the current state of corporate culture as the following: the major effect on natural culture, traditions, and customs transformed in the behavior of managers and employees (87.5\%); in the historic development of the economic, social, and political environment in Slovakia (75\%); and in the dominating sector orientation of the Slovak enterprises (75\%) (Vetraková and Smerek 2015). Enterprises processing wood and wood material in Slovakia are specific when compared to other industry areas in Slovakia. In terms of economic figures, the position of forest industry has been difficult for a long time (Hajdúchová et al. 2016). In brick and 
mortar enterprises, the employees have the possibility of horizontal-vertical-side career growth. In contrast, for the enterprises with a fixed structure (manager - white-collar worker - blue-collar worker, which wood-processing enterprises are not), it is difficult to change jobs for the employees due to the level of education. During their employment, the employees of these enterprises work the same job long-term. They do not have the possibility of career growth, and therefore they come to terms with the idea that they will do this monotonous work for their entire life. Because they have to come to terms with this, they accept the clan corporate culture long-term as the most suitable type of corporate culture for them (Deal 2007).

Further continuation of research is possible through more detailed analyses of the corporate culture based on the selected socio-demographic factors (gender, education, and age) as well as the perspective of change of corporate culture over time.

\section{CONCLUSIONS}

1. There were no significant differences in the type of corporate culture. Both analyzed groups of employees (wood-processing enterprises and forest enterprises) preferred clan corporate culture. The employees of these enterprises were working the same job long-term. They did not have the possibility of career growth and they had to come to terms with their jobs. For this reason, they accepted the clan corporate culture as the most suitable type of corporate culture. Managers are expected to create and build the clan corporate culture that is considered the best type of corporate culture for woodprocessing and forest enterprise as it is focused on the development of each person. Great attention should be paid to coherence. Success should be measured in relation to the care for the employees, useful for improving the performance and enterprise productivity.

2. Statistically significant differences in the opinions of respondents were discovered in the area of organizational leadership, despite the fact that both groups of respondents considered Organizational Leadership as a demonstration of cooperative, organized, and smooth operating performance.

3. Other significant differences were recognized in the area of criteria of success. The employees in wood-processing enterprises preferred the success to be based on the development of human resources, teamwork, employee agreement, and interest in people. The success of forest enterprises should be based on performance, reliability of deliveries, mastering logistics, and low-cost production.

4. No differences were displayed in the areas of dominant characteristics, management of employees, organization glue, and strategic emphases. Wood-processing enterprises and forest enterprises should apply teamwork and cooperation in management. The enterprises should resemble the large family with mutual contacts and have a lot in common. Enterprise strategies should focus on employees' development, trust, openness and employees' loyalty. 


\section{ACKNOWLEDGEMENTS}

This research was supported by projects VEGA No. 1/0412/19 (Systems of Human Resources Management in the 4.0 Industry Era), VEGA No. 1/0115/20 (Dependence of Corporate Culture Type Upon Selected Socio-Demographic Factors and Industries in Slovak enterprises), and APVV-17-0656 (Transformation of Paradigm in Management of Organizations in the Context of Industry 4.0).

\section{REFERENCES CITED}

Anyakoha, C. (2019). "Job analysis as a tool for improved organizational performance of SMEs in Lagos, Nigeria," Central European Journal of Labour Law and Personnel Management 2(1), 7-16. DOI: 10.33382/cejllpm.2019.02.01

Armstrong Competence Consulting Company. (2009). Handbook of Human Resource Management Practice, Kogan, London, England.

Bajzikova, L., Sajgalikova, H., Wojcak, E., and Polakova, M. (2013). "Are flexible work arrangements attractive enough for knowledge-intensive businesses?," Procedia Social and Behavioral Sciences 99, 771-783. DOI: 10.1016/j.sbspro.2013.10.549

Balážová, E., and Luptáková, J. (2016). "Application of the economic value added index in the performance evaluation of forest enterprise," Journal of Forest Science 62, 191-197. DOI: $10.17221 / 48 / 2015-J F S$

Bartuška, L., Biba, V., and Kampf, R. (2016a). "Modeling of daily traffic volumes on urban roads," in: International Conference on Traffic and Transport Engineering, Belgrade, Serbia, pp. 900-904.

Bartuška, L., Hanzl, J., and Lizbetinova, L. (2016b). "Possibilities of using the data for planning the cycling infrastructure," Procedia Engineering 161, 282-289. DOI: 10.1016/j.proeng.2016.08.555

Bauerlein, M. (2009). The Dumbest Generation: How the Digital Age Stupefies Young Americans and Jeopardizes Our Future, The Penguin Group USA Inc., New York, NY, USA.

Belias, D., Koustelios, A., Vairaktarakis, G., and Sdrolias, L. (2015). “Organizational culture and job satisfaction of Greek banking institutions," Procedia - Social and Behavioral Sciences 175, 314-323. DOI: 10.1016/j.sbspro.2015.01.1206

Bergman, M. M., Bergman, Z., and Berger, L. (2017). "An empirical exploration, typology, and definition of corporate sustainability," Sustainability 9(5), Article number 753. DOI: $10.3390 / \mathrm{su} 9050753$

Bowett, R. (2006). "Organisation - building a positive corporate culture," (http://www.tutor2u.net/business/organisation/culture_more.htm), Accessed $10 \mathrm{Jan}$ 2020.

Brown, A. D. (1995). Organizational Culture, Pitman Publishing, London, England.

Cagáňová, D., Stareček, A., Horňáková, N., and Hlásniková, P. (2019). "The analysis of the Slovak citizens' awareness about the smart city concept," Mobile Networks and Applications 24(6), 2050-2058.

Cameron, K. S., and Quinn, R. E. (2006). Diagnosing and Changing Organizational Culture: Based on the Competing Values Approach, Jessey-Bass, San Francisco, CA, USA. 
Cameron, K. S., De Graff, J., Quinn, R. E., and Thakor, A. (2006). Competing Values Leadership: Creating Value in Organisations, Edward Elgar Publishing Ltd., Cheltenham, England.

Cheung, S. O., Wong, P. S. P., and Wu, A. W. Y. W. (2011). "Towards an organizational culture framework in construction," International Journal of Project Management 29(1), 33-44. DOI: 10.1016/j.ijproman.2010.01.014

Colyer, S. (2000). "Organizational culture in selected western Australian sport organizations," Journal of Sport Management 14, 321-341.

Coyle, D. (2018). The Culture Code: The Secrets of Highly Successful Groups, Bantam Books, New York, NY, USA.

Cui, X., and Hu, J. (2012). "A literature review on organizational culture and corporate performance," International Journal of Business Administration 3(2), 29-37.

Da Silva, N., Hutcheson, J., and Wahl, G. D. (2010). "Organizational strategy and employee outcomes: A person-organization fit perspective," Journal of Psychology: Interdisciplinary and Applied 144(2), 145-161.

De Waal, A., Peters, L., and Broekhuizen, M. (2017). "Do different generations look differently at high performance organizations?," Journal of Strategy and Management 10, 86-101. DOI: 10.1108/JSMA-10-2015-0083

Deal, J. J. (2007). Retiring the Generation Gap: How Employees Young and Old One Find Common Ground, Jossey-Bass, San Francisco, CA, USA.

Deal, T. B., and Kennedy, A. A. (1982). Corporate Cultures, Penguin Books, London, England.

Denison, D. R., and Spreitzer, G. M. (1991). "Organizational culture and organizational development," in: Research in Organizational Change and Development 5, JAI Press, Greenwich, CT, USA, pp. 1-21.

Forest Europe (2015). "State of Europe's Forests 2015," (www.foresteurope.org), Accessed 10 Jan 2020.

Ghorbanhosseini, M. (2013). "The effect of organizational culture, teamwork and organizational development on organizational commitment: The mediating role of human capital," Tehnicki Vjesnik 20(6), 1019-1025.

Gordon, G. G., and Ditomaso, N. (1992). "Predicting corporate performance from organizational culture," Journal of Management Studies 29(6), 783-798.

Hajdúchová, I., Sedliačiková, M., Halaj, D., Krištofík, P., Musa, H., and Viszlai, I. (2016). "Slovakian forest-based sector in the context of globalization," BioResources 11(2), 4808-4820. DOI: 10.15376/biores.11.2.4808-4820

Halaj, D., Sedliacikova, M., and Mala, D. (2018). "Customer behavior on the Slovakian roundwood market: A case study," BioResources 13(3), 6003-6020. DOI:

10.15376/biores.13.3.6003-6020

Handy, C. (1985). Understanding Organizations, Penguin Books, London, England.

Harrison, R. (1972). “Understanding your organization's character," Harvard Business Review, Available at (https://bschool.pepperdine.edu/masters-degree/organizationdevelopment/content/parttwo-chapterten.pdf), pp. 1-28.

Hershatter, A., and Epstein, M. (2010). "Millennials and the world of work: An organization and management perspective," Journal of Business Psychology 25, 211223. DOI: 10.1007/s10869-010-9160-y 
Hofstede, G., Hofstede, G., and Fink, G. (2007). "Culture: Organizations, personalities and nations," Gerhard Fink Interviews European Journal of International Management $1(1 / 2), 14-22$.

Horváth, Z., and Hollósy, V. G. (2019). "The revision of Hungarian public service motivation (PSM) model," Central European Journal of Labour Law and Personnel Management 2(1), 17-28. DOI: 10.33382/cejllpm.2019.02.02

Huang, Q. V., Davison, R. M., Liu, H. F., and Gu, J. B. (2008). "The impact of leadership style on knowledge-sharing intentions in China," Journal of Global Information Management 16(4), 67-91. DOI: 10.4018/jgim.2008100104

Jahanian, M., and Amini, M. T. (2015). "The effect of suitable organizational culture on implementing strategy (case study: Telecommunication company of Hamedan)," International Business Management 9(7), 1809-1816.

Jančíková, A. (2005). Organizační Kultura a Řizení Kvality: Závěry z Emprických Šetření [Organizational Culture and Quality Management: Conclusions from Empress Investigations], Masarykova Univerzita, Brno, Czech Republic.

Jenco, M., Droppa, M., Lysa, L., and Križo, P. (2018). "Assessing the quality of employees in terms of their resistance," Quality-Access to Success 19(167), 48-53.

Joniakova, Z., and Blstakova, J. (2015). "Age management as contemporary challenge to human resources management in Slovak companies," Procedia Economics and Finance 34, 202-209. DOI: 10.1016/S2212-5671(15)01620-2

Kachaňáková, A. (2010). Organizačná Kultúra [Organizational Culture], Iura Edition, Bratislava, SR.

Kachaňáková, A., and Stachová, K. (2014). "Present state of organizational culture in Slovakia,” Economic Annals-XXI 3-4(1), 35-38.

Kachaňáková, A., Szarková, M., and Thomasová, E. (1997). Podniková Kultúra [Company Culture], EKONÓM, Bratislava, SR.

Kets de Vries, M. F., and Miller, D. (1984). The Neurotic Organization, Jossey-Bass, San Francisco, CA, USA.

Kmecová, I. (2018). "Educational process and motivation factors of university students and its analysis," in: Innovation Management and Education Excellence Through Vision 2020, International Business Information Management Association, Milan, Italy, pp. 1815-1824.

Kohnová, L., Papula, J., and Salajová, N. (2019). "Internal factors supporting business and technological transformation in the context of industry 4.0," Business: Theory and Practice 20, 137-245. DOI: 10.3846/btp.2019.13

Kotter, J. P., and Heskett J. L. (1992). Corporate Culture and Performance, Free Press, New York, NY, USA.

Koval'ová, M., Hvolková, L., Klement, L., and Klementová, V. (2018). "Innovation strategies in the Slovak enterprises," Acta Oeconomica Universitatis Selye 7, 79-89.

Kreitner, R., and Kinicki, A. (2001). Organizational Behavior, McGraw-Hill, New York, NY, USA.

Kropivšek, J., Jelačić, D., and Grošelj, P. (2011). "Motivating employees of Slovenian and Croatian wood-industry companies in times of economic downturn," Drvna Industrija 62(2), 97-103. DOI: 10.5552/drind.2011.1040

Kucharčíková, A., and Mičiak, M. (2017). "Human capital management in transport enterprise," in: International Scientific Conference on LOGI, Ceske Budejovice, Czech Republic, pp. 1-8. 
Kucharčíková, A., and Mičiak, M. (2018). "Human capital management in transport enterprises with the acceptance of sustainable development in the Slovak Republic," Sustainability 10(7), Article number 2530. DOI: 10.3390/su10072530

Kucharčíková, A., Tokarčíková, E., and Durišová, M. (2015). "Human capital efficiency in trading company," in: International Days of Statistics and Economics, Melandrium Company, Prague, Czech Republic, pp. 892-901.

Lencioni, P. (2002). The Five Dysfunctions of a Team: A Leadership Fable, Jossey-Bass, San Francisco, CA, USA.

Ližbetin, J., Stopka, O., and Němec, F. (2016). "Methodological assessment of environmental indicators in combined transport in comparison with direct road freight transport," in: International Scientific Conference Transport Means 2016, Juod Krante, Lithuania, pp. 151-155.

Lizbetinova, L. (2014). "The quality of communication in the context of regional development," Deturope-The Central European Journal of Regional Development and Tourism 6(3), 22-38.

Lizbetinova, L. (2017). "Clusters of Czech consumers with focus on domestic brands," in: International-Business-Information-Management-Association Conference Sustainable Economic Growth, Education Excellence, and Innovation Management Through Vision 2020, International Business Information Management Association, Vienna, Austria, pp. 1703-1718.

Loucanova, E., Olsiakova, M., and Dzian, M. (2018). "Suitability of innovative marketing communication forms in the furniture industry," Acta Facultatis Xylologiae Zvolen 60(1), 159-171. DOI: 10.17423/afx.2018.60.1.17

Lukášová, R. (2010). Organizační Kultura a Její Změna [Organizational Culture and its Change], Grada Publishing, Prague, Czech Republic.

Lukášová, R., and Nový, I. (2004). Organizational Culture, Grada Publishing, Prague, Czech Republic.

Mala, D., Sedliacikova, M., Drabek, J., Jelacic, D., and Minarova, M. (2019). "Consumer perception of environmentally sustainable products of Slovak wood processing enterprises," Drvna Industrija 70(4), 407-418. DOI: 10.5552/drvind.2019.1922

McCready, V. (2011). "Generational issues in supervision and administration," The ASHA Leader 1, 12-15.

McNamara, C. (2006). "Basic overview of organizational culture," Authenticity Consulting, LLC, (http://www.managementhelp.org/org_thry/culture/culture.htm), Accessed 8 Dec 2016.

McShane, S. L., and Von Glinow, M. A. (2000). Organizational Behavior, McGraw-Hill, New York, NY, USA.

Miles, R. E., and Snow, C. C. (1978). Organization Strategy, Structure, and Process, McGraw-Hill, New York, NY, USA.

Ministerstvo Pôdohospodárstva a Rozvoja Vidieka Slovenskej Republiky [Ministry of Agriculture and Rural Development of the Slovak Republic] (2017). "Správa o Pol'nohospodárstve a Potravinárstve v Slovenskej Republike za Rok 2016 [Report on agriculture and food in the Slovak Republic for 2016]," MPSR, (https://www.mpsr.sk/zelena-sprava-2017/122---12419/), Accessed 5 Dec 2019.

Muhtadi, A., Hilmi, I. L., Supriyatna, Kautsar, A. P., Widianto, S., and Abdulah, R. (2013). "Hospital pharmacist's employee engagement fully mediate the organization 
culture to their innovative behavior and individual performance," International Journal of Pharmaceutical Sciences Review and Research 23(1), 183-190.

Mullakhmetov, K. S., Sadriev, R. D., and Akhmetshin, E. M. (2019). "Influence of corporate culture on the system of management in modern conditions," Entrepreneurship and Sustainability Issues 7(2), 1098-1113. DOI: 10.9770/jesi.2019.7.2(22)

Musová, Z. (2015). "Consumer attitudes to cause related marketing in Slovakia," Acta Oeconomica Universitatis Selye 4(1), 93-105.

Nedeliakova, E., and Panak, M. (2015). "New trends in process-oriented quality management," Procedia Economics and Finance 34, 172-179. DOI: 10.1016/S22125671(15)01616-0

Nedeliakova, E., Panak, M., Ponicky, J., and Sousek, R. (2016). 'Progressive management tools for quality improvement application to transport market and railway transport," AER-Advances in Engineering Research 62, 195-198. DOI: 10.2991/esm-16.2016.45

Nemec, M., Krišt'ák, L., Hockicko, P., Danihelová, Z., and Velmovská, K. (2017). "Application of innovative P\&E method at technical universities in Slovakia," Eurasia Journal of Mathematics Science and Technology Education 13(6), 23292349. DOI: 10.12973/eurasia.2017.01228aa

Ng, E. S. W., and Schweitzer, L. (2010). "New generation, great expectations: A field study of the millennia generation," Journal of Business and Psychology 25, 281-292. DOI: $10.1007 / \mathrm{s} 10869-010-9159-4$

Nukic, I. S., and Huemann, M. (2016). "Organizational culture of the Croatian construction industry," Engineering, Construction and Architectural Management 23(2), 237-260. DOI: 10.1108/ECAM-02-2015-0019

Nyuur, R., Brečić, R., and Murphy, P. (2020). "Managerial perceptions of firms' corporate sustainability strategies: Insights from Croatia," Sustainability 12(1), Article number 251. DOI: $10.3390 /$ su12010251

Nyvlt, V. (2018). "The role of managing knowledge and information in BIM implementation processes in the Czech Republic," in: International Scientific Conference Building Defects, Volume 146, Ceske Budejovice, Czech Republic, pp. 16. DOI: 10.1051/matecconf/201814601003

Oblak, L., Barcic, A. P., Klaric, K., Kuzman, M. K., and Groselj, P. (2017). "Evaluation of factors in buying decision process of furniture consumers by applying AHP method," Drvna Industrija 68(1), 37-43. DOI: 10.5552/drind.2017.1625

Ogbonna, E., and Harris, L. C. (2000). "Leadership style, organizational culture and performance: Empirical evidence from UK companies," International Journal of Human Resource Management 11(4), 766-788.

Paluš, H., Kaputa, V., Parobek, J., Šupín, M., Halaj, D., Šulek, R., and Fodrek, L. (2011). Trh s Lesníckymi Službami [Forestry Services Market], Technická Univerzita vo Zvolene [Technical University of Zvolen], Zvolen, SR.

Palus, H., Parobek, J., Dzian, M., Simo-Svrcek, S., and Krahulcova, M. (2019). "How companies in the wood supply chain perceive the forest certification," Acta Facultatis Xylologiae Zvolen 61(1), 155-165. DOI: 10.17423/afx.2019.61.1.15

Papula, J., Kohnova, L., and Papulova, Z. (2018). "Impact of national culture on innovation activities of companies: A case of Germany, Austria, Switzerland and the Czech Republic,” Economic Annals-XXI 169(1-2), 26-30. DOI: 10.21003/ea.V169-05 
Parker, C. P., Baltes, B. B., Young, S. A., Huff, J. W., Altmann, R. A., Lacost, H. A., and Roberts, J. E. (2003). "Relationships between psychological climate perceptions and work outcomes: A meta-analytic review," Journal of Organizational Behavior 24(4), 389-416. DOI: 10.1002/job.198

Parobek, J., Palus, H., Moravcik, M., Kovalcik, M., Dzian, M., Murgas, V., and SimoSvrcek, S. (2019). "Changes in carbon balance of harvested wood products resulting from different wood utilization scenarios," Forests 10(7), Article number 590. DOI: 10.3390/f10070590

Parthasarathy, K., and Ramalingam, S. (2015). "An empirical study on organization culture and its impact on employee motivation with reference to industrial estates in Chennai," International Journal of Applied Business and Economic Research 13(1), 287-294.

Pfeifer, L., and Umlaufová, M. (1993). Firemní Kultura: Síla Sdílených Cílů, Hodnot a Priorit [Corporate Culture: The Power of Shared Goals, Values and Priorities], Grada Publishing, Prague, Czech Republic.

Poliačiková, E. (2015). "Key account management as an innovation form of entry to customers in Slovakia," Acta Oeconomica Universitatis Selye 4(1), 135-145.

Potkany, M., Stasiak-Betlejewska, R., Kovac, R., and Gejdos, M. (2016). "Outsourcing in conditions of SMEs - The potential for cost savings," Polish Journal of Management Studies 13(1), 145-156. DOI: 10.17512/pjms.2016.13.1.14

Quinn, R., and Rohrbaugh, J. (1983). "A spatial model of effectiveness criteria: Toward a competing values approach to organizational analysis," Management Science 29(3), 363-377. DOI: $10.1287 / \mathrm{mnsc} .29 .3 .363$

Radovic-Markovic, M. (2008). "Managing the organizational change and culture in the age of globalization," Journal of Business Economics and Management 9(1), 3-11. DOI: 10.3846/1611-1699.2008.9.3-11

Ravasi, D., and Schultz, M. (2006). "Responding to organizational identity threats: Exploring the role of organizational culture," The Academy of Management Journal 49(3), 433-458. DOI: 10.5465/AMJ.2006.21794663

Remisova, A., Lasakova, A., and Kirchmayer, Z. (2019). "Influence of formal ethics program components on managerial ethical behavior," Journal of Business Ethics 160(1), 151-166. DOI: 10.1007/s10551-018-3832-3

Rezaei, G., Mardani, A., Senin, A. A., Wong, K. Y, Sadeghi, L., Najmi, M., and Shaharoun, A. M. (2016). "Relationship between culture of excellence and organizational performance in Iranian manufacturing companies," Total Quality Management and Business Excellence 29(1-2), 94-115. DOI: 10.1080/14783363.2016.1168692

Saffold, G. (1988). "Culture traits, strength, and organizational performance: Moving beyond "strong" culture," Academy of Management Review 13, 546-558.

Sánchez-Sellero, M. C., Sánchez-Sellero, P., Cruz-González, M. M., and SánchezSellero, F. J. (2018). "Determinants of job satisfaction in the Spanish wood and paper industries: A comparative study across Spain," Drvna Industrija 69(1), 71-80. DOI: 10.5552/drind.2018.1711

Santos, S., and Cox, K. (2000). "Workplace adjustment and intergenerational differences between matures, boomers, and Xers," Nursing Economic\$18(1), 7-13.

Schein, E. H., and Schein P. A. (2016). Organizational Culture and Leadership, 5th Edition, Jossey-Bass Business and Management Series, San Francisco, CA, USA. 
Schimmoeller, L. (2010). "Leadership styles in competing organizational cultures," Leadership Review 10(3), 125-141.

Scott, D. K. (1997). "Managing organizational culture in intercollegiate athletic organizations," Quest 49(4), 403-415. DOI: 10.1080/00336297.1997.10484257

Škerlavaj, M., Dimovski, V., Černe, M., Kekenovski, L., Tevdovski, D., and Trpkova, M. (2011). "The organisational learning culture and organisational performance in Macedonian companies," European Journal of International Management 5(6), 574607. DOI: 10.1504/EJIM.2011.042733

Stacho, Z., and Stachova, K. (2015). "The extent of education of employees in organisations operating in Slovakia," in: 12 ${ }^{\text {th }}$ International Conference on Efficiency and Responsibility in Education, Prague, Czech Republic, pp. 548-555.

Steinmann, H., and Schreyögg, G. (1993). Management Grundlagen der Unternehmensfurung, Koncepte-Funktionen-Fallstudien [Management Basics of Corporate Management, Concept Functions, Case Studies], Springer Gabler, Wiesbaden, Germany.

Suchomel, J., and Gejdos, M. (2007). "Analysis of wood resources and price comparation in Slovakia and selected countries," in: International Scientific Conference on Woodworking Technique, Zagreb, Croatia, pp. 143-152.

Suchomel, J., and Gejdos, M. (2010). "The influence of selected factors on the occurrence of false heartwood in beech (Fagus sylvatica)," Acta Facultatis Xylologiae Zvolen 52(1), 5-13.

Sujová, K., and Kovalčík, M. (2017). "Development of the business sector in Slovakian forestry - Business companies," in: Conference Aktuálne Otázky Ekonomiky A Politiky Lesného Hospodárstva Slovenskej Republiky [Conference Current Issues of Economy and Forestry Policy of the Slovak Republic], Bratislava, Slovakia, pp. 17-22.

Urbancova, H., Vnouckova, L., and Laboutkova, S. (2016). "Knowledge transfer in a knowledge-based economy," E \& M Ekonomie a Management 19(2), 73-86.

Uriga, J., and Obdržálek, P. (2009). "Vzt’ah firemnej kultúry a výkonu a ich prepojenie na obchodné výsledky [Relationship between corporate culture and performance and their link to business results]," Personálny Manažment [Personal Management] 2009, 90-96.

Vallejo-Martos, M. C. (2011). "The organizational culture of family firms as a key factor of competitiveness," Journal of Business Economics and Management 12(3), 451-481. DOI: 10.3846/16111699.2011.599407

Vetraková, M., Holubekova, K., and Sebova, L. (2015). "Use of intercultural differences in tourism marketing," in: International Colloquium on Regional Sciences, Hustopece, Czech Republic, pp. 722-728.

Vetraková, M., and Smerek, L. (2015). “Zmena podnikovej kultúry slovenských podnikov [Change of corporate culture of Slovak enterprises]," Ekonomika a Spoločnost' 16(1), 36-127.

Vetraková, M., and Smerek, L. (2016). "Diagnosing organizational culture in national and intercultural context," E \& M Ekonomie a Management 19(1), 62-73. DOI: 10.15240/tul/001/2016-1-005

Vlaicu, F. L., Neagoe, A., Țîru, L. G., and Otovescu, A. (2019). "The organizational culture of a major social work institution in Romania: A sociological analysis," Sustainability 11(13), 3587. DOI: 10.3390/su11133587 
Wilderom, C. P. M., Glunk, U., and Maslowski, R. (2000). "Organizational culture as a predictor of organizational performance," in: Handbook of Organizational Culture and Climate, N. M. Ashkanasy, C. P. M. Wilderom, and M. F. Peterson (eds.), Sage Publications, Thousand Oaks, CA, USA, pp. 88-95.

Willar, D., Trigunarsyah, B., and Coffey, V. (2016). "Organizational culture and quality management system implementation in Indonesian construction companies," Engineering, Construction and Architectural Management 23(2), 114-133. DOI: 10.1108/ECAM-02-2015-0026

Yeung, A. K. O., Brockbank, J. W., and Ulrich, D. O. (1991). “Organizational culture and human resource practices: An empirical assessment," in: Research in Organizational Change and Development 5, JAI Press, Greenwich, CT, USA, pp. 59-81.

Yong, K. T., and Pheng, L. S. (2008). "Organizational culture and TQM implementation in construction firms in Singapore," Construction Management and Economics 26(3), 237-248. DOI: 10.1080/01446190701874397

Zaborova, E. N., Glazkova, I. G., and Markova, T. L. (2017). "Distance learning: Students' perspective," Sotsiologicheskie Issledovaniya 2017(2), 131-139.

Zammuto, R. F., and Krakower, J. Y. (1991). "Quantitative and qualitative studies of organizational culture," in: Research in Organizational Change and Development 5, W. A. Pasmore, and R. W. Woodman (eds.), JAI Press, Greenwich, CT, USA, pp. 83-114.

Article submitted: January 27, 2020; Peer review completed: March 14, 2020; Revised version received and accepted: March 19, 2020; Published: March 24, 2020.

DOI: 10.15376/biores. 15.2.3320-3343 